\section{Upward Movement in Energy Prices}

Energy prices have risen strongly recently, and consequently become a controversial issue in economic policy. The rises are due to a number of factors - turbulence on the international oil market and its effects on other energy markets, price increases for environmental reasons and delays in liberalising and regulating electricity and gas supplies.

International oil prices reached a record level in October 2004. Coal prices followed, as did gas prices after a delay of a few months. Moreover, energy prices in Germany are relatively high by European comparison, for both private households and industrial customers. While the differences in fuel prices are almost entirely due to higher taxation, there are other reasons as well for the increases in prices for electricity and gas.

\section{Crude oil prices}

In mid-October 2004 the price for a barrel (159 litres) of Brent crude rose to more than 50 US dollars, which was 10 US dollars above the previous peak in 1981. However, if the fall in the value of money due to the general rise in prices is taken into account it was still around $40 \%$ below that level (cf. figure 1).

The current surge in prices has been caused by greater demand for oil, individual production shortfalls and speculation on the forward markets for oil, against the background of a shortage in extraction capacities. Past short-term fluctuations in oil prices were strongly influenced by the level of commercial crude oil stocks in the OECD. However, in July 2004 these were 924 million barrels, about the same level as in 1999, when the price for crude was not even half as high as today.

In the first half of 2004 about 1 million barrels a day $(\mathrm{mbd})$ more oil was produced worldwide than was consumed. Consequently, total crude oil stocks in the OECD countries rose, and they are now back above the average for the last five years. In the third quarter of this year the production overhang may be assumed to have increased again. If OPEC maintained its present level of output in the fourth quarter total output of crude would be clearly above demand, even during the heating period (assuming normal weather conditions), and the crude oil stocks would rise further. With the present level of OPEC output, crude oil prices ought actually to be falling markedly.
The speculation on the forward oil markets is ultimately due to the currently very high utilisation of production capacities in OPEC. ${ }^{1}$ In order to remove the basis for this speculation and achieve a lasting correction of the currently very high price for crude oil, OPEC needs to make the international community believe that output capacity will increase greatly in the next few years. As long as the production capacities are not substantially increased the price risks will persist. ${ }^{2}$

\section{Fuel prices}

At around 1.20 euros a litre for standard petrol and more than 1 euro a litre for diesel, fuel prices in Germany are now about $50 \%$ higher than in the high price phase of

\section{Figure 1}

\section{Prices for Brent Crude 1970 to $2004^{2}$ Price per barrel}

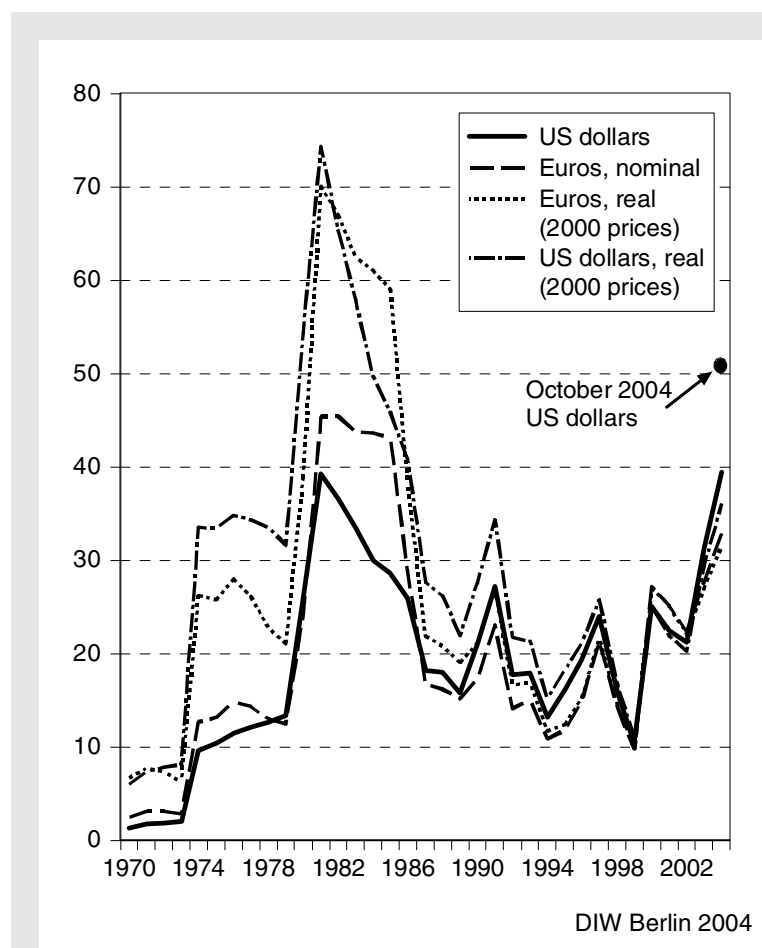

1 Until 1979 Saudi Arabian Light. - 2 Estimated for 2004

Sources: Petroleum Intelligence Weekly, diverse issues; German Bundesbank; US Department of Labor; Bureau of Labor Statistics; Consumer Price Index, Washington D.C., 1 October 2004; DIW Berlin calculations.

1 OPEC's production capacities are currently $32 \mathrm{mbd}$; demand for OPEC oil without the current stockpiling is $28 \mathrm{mbd}$.

2 On the influence of the oil price on the economic situation see: 'The World Economy and the German Economy in the Autumn of 2004', DIW Berlin Economic Bulletin, vol. 41, no. 11, November 2004. 
the early 1980s; adjusted for inflation these prices are about back at the historic peak for fuel prices of 1981 (cf. figure 2).

With tax rates on petroleum almost unchanged, fuel prices fell at the end of the 1980s from around 70 cents (nominal) to less than 50 cents. Petrol and diesel fuel were then subject to almost the same rate of tax and cost about the same at the filling station. Since the low in 1988 fuel prices have roughly doubled. Until the mid1990s the rise in prices was driven exclusively by tax rises, but then came both tax increases and higher product prices. ${ }^{3}$

With the gradual but strong increases in petroleum tax from 1989 the share of tax in the price of petrol had risen to nearly $80 \%$ by $1994 / 1995 .{ }^{4}$ Since early 1999 there have been further leaps in prices, due in about equal parts to the five stages of the eco-tax (nearly 18 cents including turnover tax) and the rise in product prices (a good 20 cents). At present tax accounts for three quarters of the price of petrol and about two thirds of the diesel price. ${ }^{5}$ The high prices have contributed to the fall in sales of vehicle fuel since $1999 .^{6}$

There are big differences in fuel prices between European countries, and these are due almost entirely to the different rates of tax. ${ }^{7}$ At present only in two countries are the prices higher than in Germany (cf. figure 3).

\section{Hard coal}

Hard coal mining in Germany is not competitive, and it is being reduced under coal policy agreements, with imports of hard coal increasing to compensate. ${ }^{8}$ Ger-

\footnotetext{
3 Since 1 January 2003, after the fifth and final stage of the ecological tax reform, the tax rates have been 654.50 euros per 1000 litres of unleaded and sulphur-free petrol, and 470.40 euros per 1000 litres of sulphur-free diesel fuel.

4 Even in the early 1970s tax (petroleum and turnover taxes) accounted for about $70 \%$ of prices at the filling station. In real terms (in 2000 prices), fuel in 1970 cost about 75 cents a litre (including turnover tax), just under 50 cents of which was petroleum tax.

${ }^{5}$ In consideration of the need to keep the German road transport sector competitive the increases in petroleum tax were not, or not fully, applied to diesel fuel. As compensation, road tax on diesel cars was increased in 1989 and 1991.

${ }^{6}$ Cf. Jutta Kloas, Hartmut Kuhfeld and Uwe Kunert: 'Strassenverkehr: Eher Ausweichreaktionen auf hohe Kraftstoffpreise als Verringerung der Fahrleistungen', in: Wochenbericht des DIW Berlin, no. 41/2004, pp. 602-612.

7 For the countries shown in figure 3 the rates of tax per 1000 litres range from 215 to 701 euros on diesel fuel and 296 to 701 euros on petrol.

${ }^{8}$ In 2003 imported hard coal accounted for just under $60 \%$ of German consumption, cf. P. Hufschmied: 'Der deutsche Steinkohlenmarkt im Jahr 2003', in: Glückauf, 140 (4), 2004, pp. 182-189.
}

Figure 2

\section{Fuel Prices ${ }^{1}$ and Petroleum Tax in Germany ${ }^{2}$ 1970 to $2004^{3}$}

In cents per litre
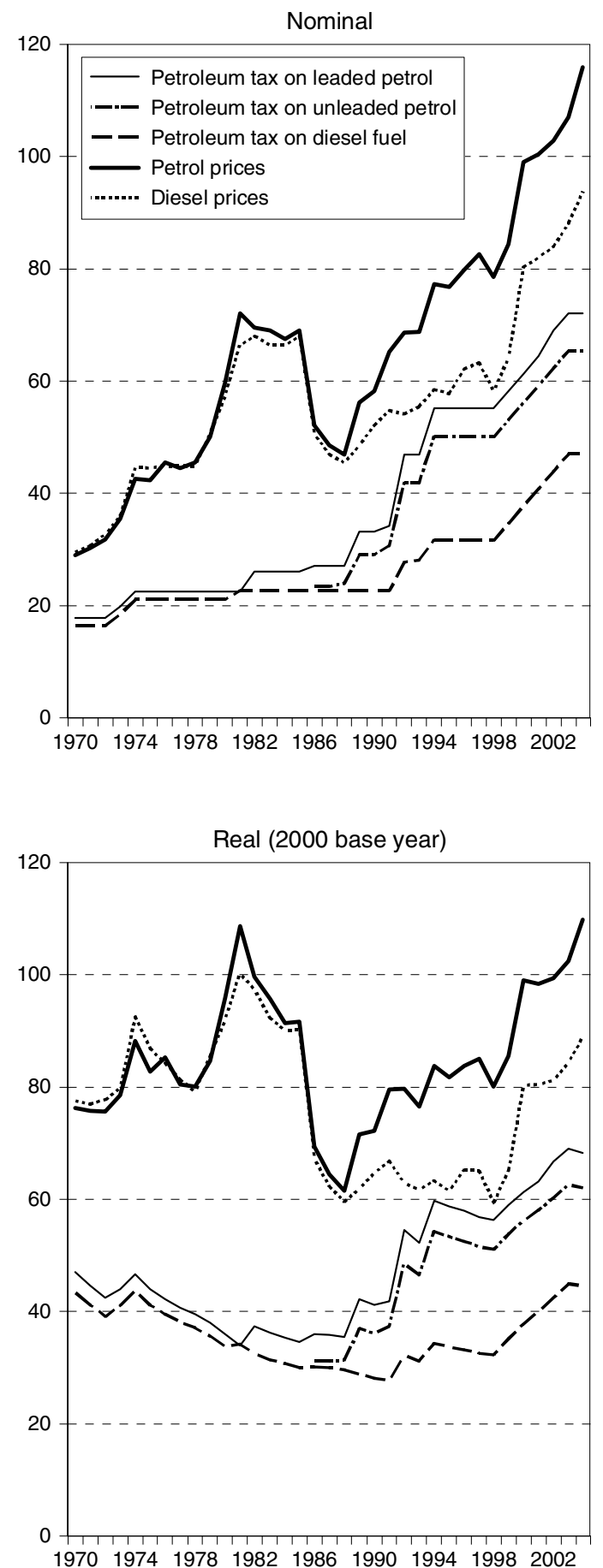

DIW Berlin 2004

1 Fuel prices are up to 1987 for leaded standard petrol and from 1988 for unleaded standard petrol. - 2 Until 1990 West Germany. - 3 Preliminary figures for 2004. Sources: Aral; KBA. 
Figure 3

Fuel Prices in Europe in June 2004

In euros per litre

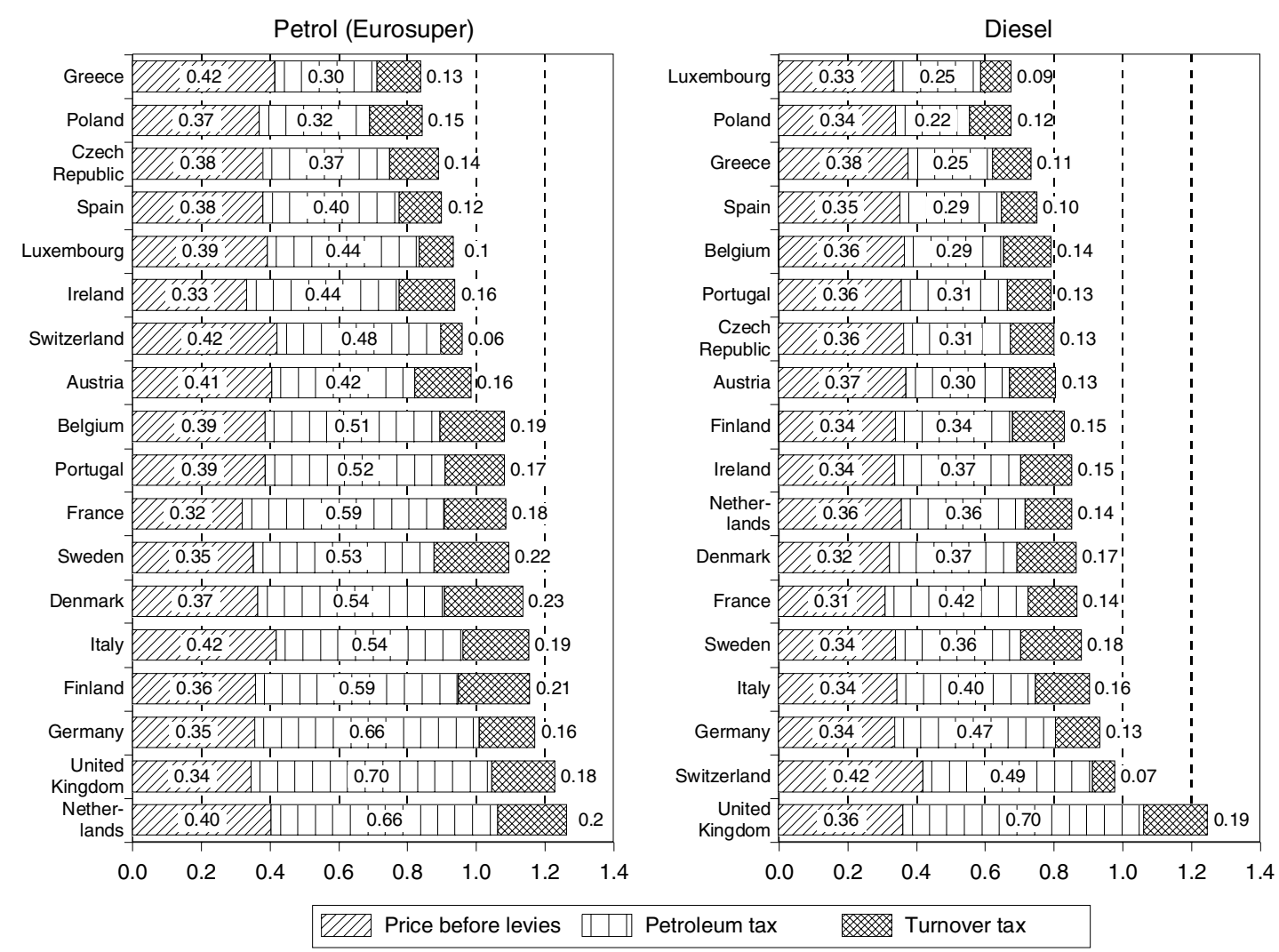

DIW Berlin 2004

Sources: European Commission; www.clever-tanken.de; DIW Berlin calculations

many's main sources of supply are Poland, South Africa, Russia, Colombia and Australia. ${ }^{9}$

The price of imported steam coal, which is used mainly in power stations, has been about half as high as the price of crude oil on average for the last three decades - in terms of value. During that period it fluctuated between 36 and 101 euros per tonne of coal equivalent (tce) and thus far less than the oil price (cf. figure 4). However, there is evidently a strong correlation between these prices, and that also applies, to a slightly lesser extent, to coking coal for the steel industry. This means that the development in prices for imported coal is largely determined by the developments on the world market for oil.

\footnotetext{
${ }^{9}$ On the developments in the world market for hard coal and coal imports see Verein der Kohlenimporteure (VDKI): 'Jahresbericht 2003'; VDKI Press release of 24 June 2004; Statistik der Kohlenwirtschaft e.V. (www.kohlenstatistik.de), 23 September 2004).
}

During the second half of 2003 FOB prices for steam coal quoted in US dollars ${ }^{10}$ rose strongly (to 42 to 48 US dollars per $\mathrm{t}$ ). This was due to increases in demand and to previous adjustments of output in South Africa and Colombia. Prices for coking coal rose dramatically, and coke prices escalated even more drastically.

At the same time freight rates rose strongly, as bottlenecks were caused by demand for other bulk goods. Rates in 2003 were more than twice the 2002 level (e.g. from South Africa to the Netherlands a leap from 6.50 to 14.80 US dollars per $\mathrm{t}$ ).

The rise in FOB prices and in freight rates brought high cost, insurance, freight (CIF) prices in 2003 as well, although this development was lessened in Europe by the development in the exchange rate. The average annual import price (cross-border price) for steam coal

${ }^{10}$ FOB free on board, that is, without the costs of insurance and freight. 
Figure 4 Import Prices for Selected Energy Sources
in Germany 1970 to $2004^{1}$

In euros per tonne of coal equivalent (tce)

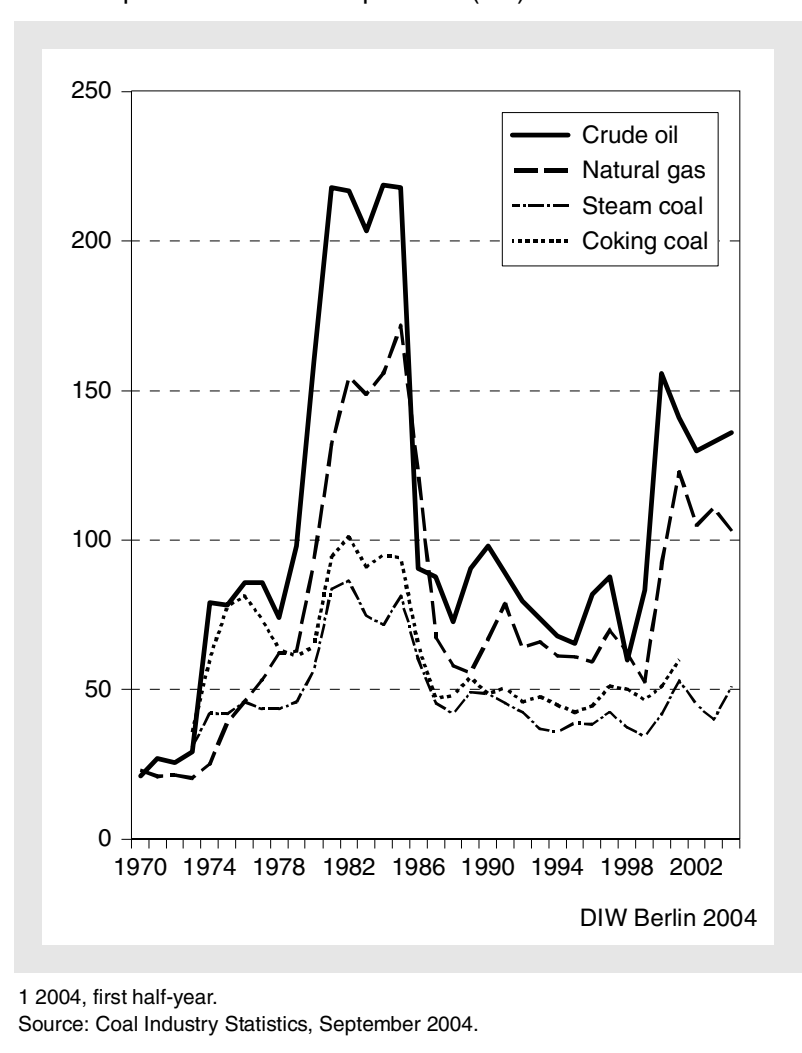

was around 40 euros per $t$ in 2003 , which was actually $10 \%$ below the 2002 price. However, the price rose strongly in 2004, although freight rates were falling again, reaching 49 euros per $t$ in the first quarter and 55 euros per $t$ in the second. However, compared with the prices for oil and gas, which are still much higher, imported steam coal is still very competitive. ${ }^{11}$

The price of imported coking coal rose to around 80 euros per $\mathrm{t}$ in the first half of $2004,{ }^{12}$ but prices for coke rose much more strongly. Prices for Chinese coke, for instance, which had doubled to around 150 US dollars from mid-2002 to mid-2003, rose again to 460 US dollars per $\mathrm{t}$ (FOB) by April 2004, as exports were cut back strongly. Although the price had fallen back to 270 US dollars per $t$ by July, an end to the turbulence on the international coke market is not yet in sight. ${ }^{13}$ However, the turbulence is not affecting developments on the coal

\footnotetext{
11 The average price of hard coal free to the power station is around 5 euros above the cross-border price. In the fourth quarter of 2003 it was 47 euros per tce, considerably below the corresponding prices for natural gas (174 euros per tce) and heavy heating oil (119 euros per tce).

12 VDI Nachrichten, 24 September 2004.
}

\section{Figure 5 \\ Gas Prices ${ }^{1}$ in Germany 1996 to 2004}

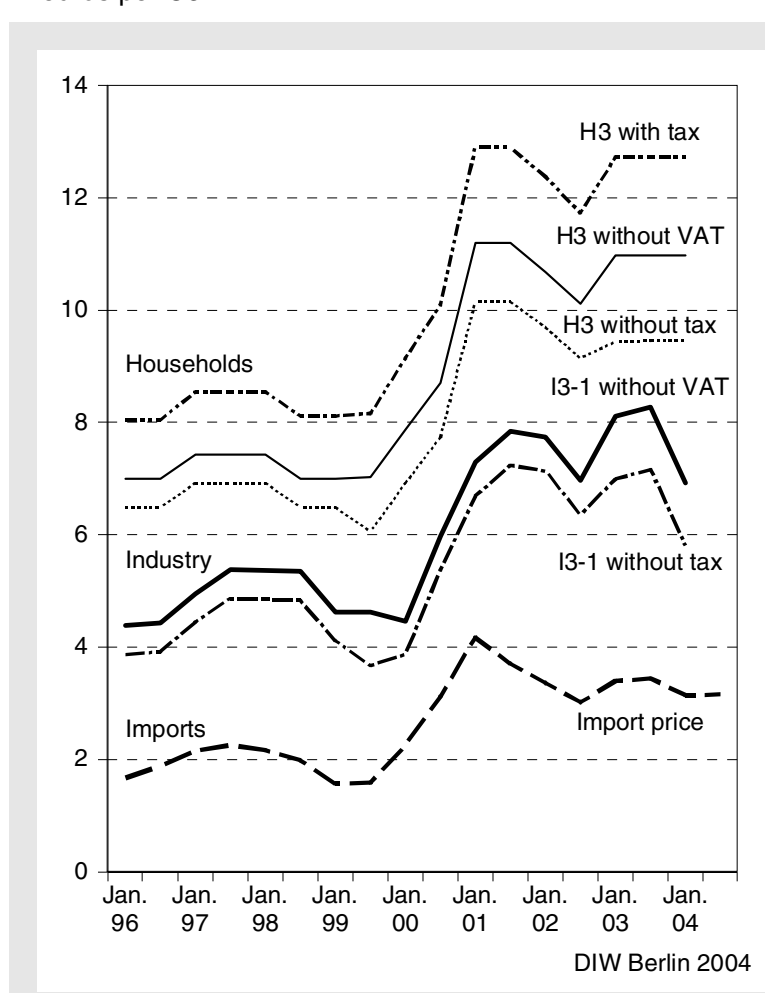

1 Import price according to BAFA; prices for households (consumer type $\mathrm{H} 3$ ) and industry (consumer type I3-1) in Dortmund according to Eurostat. Sources: BAFA; Eurostat.

markets, nor does it justify any reassessment of coal policy.

\section{Natural gas}

Four fifths of Germany's supply of natural gas is imported, mainly from Russia, Norway and the Netherlands. The price of imported natural gas follows the development in crude oil prices with a timelag of about six months, and it is subject to similar fluctuations (cf. figures 4 and 5). Long-term supply contracts for natural gas couple the price to the price of oil in accordance with the 'viability' principle traditional in the gas industry. On average for the last three decades the import price for natural gas was around $75 \%$ of the import price for

\footnotetext{
13 Dieter Ameling: 'Stahl im Focus. Anmerkungen zur aktuellen Lage auf den Rohstoff- und Stahlmärkten', Wirtschaftsvereinigung Stahl, Mimeo, 28 July 2004. On the situation in Chinese coke see Jürgen Kasperczyk: 'Zu Angebot und Nachfrage von Koks in China im 1. Halbjahr 2004', in: stahl und eisen, 124 (9), 2004, pp. 37-49.
} 


\section{Figure 6}

\section{Gas Prices for Households ${ }^{1}$ and Industry ${ }^{2}$ in Europe on 1 January 2004 In euros per GJ}
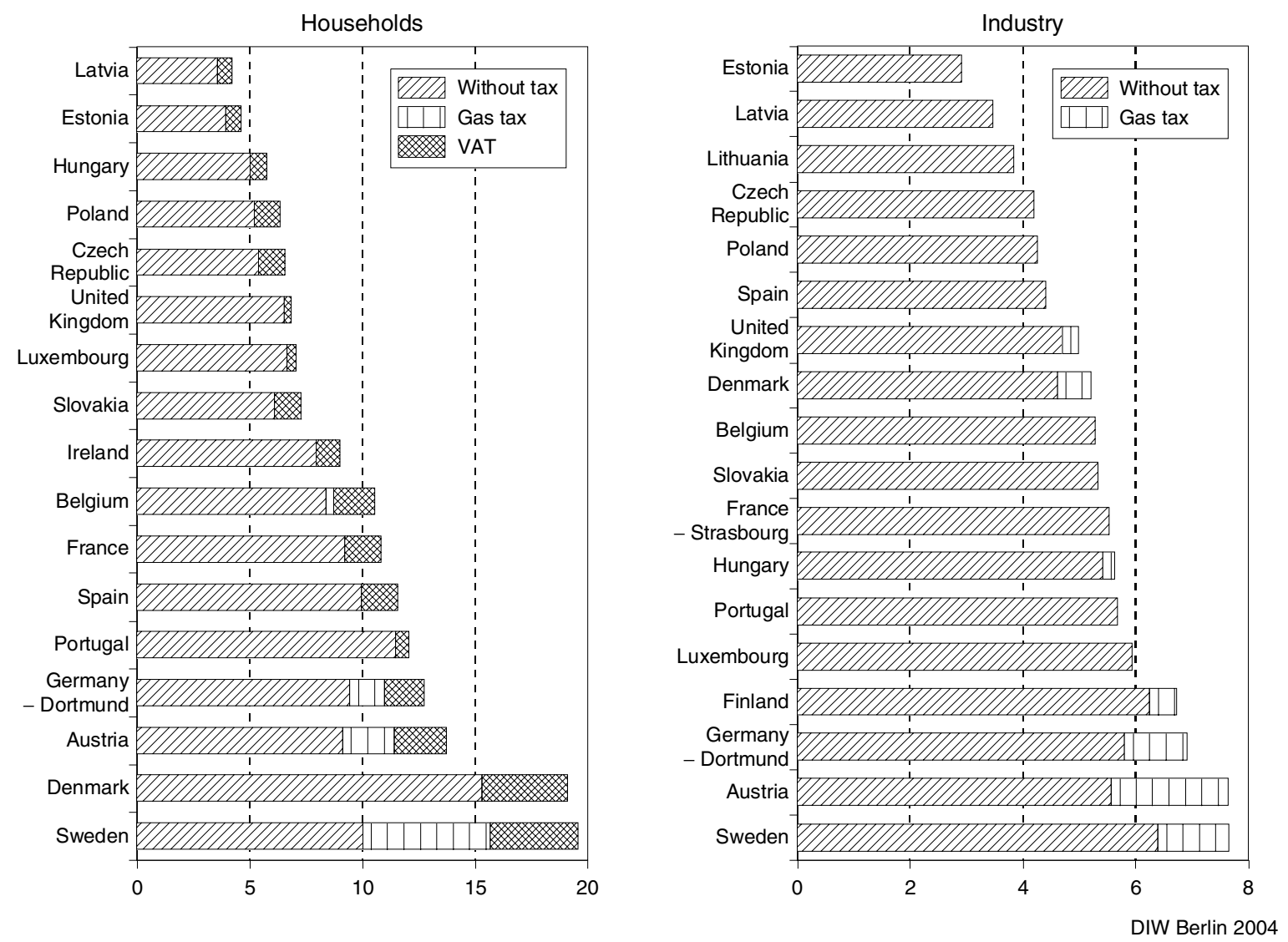

1 Consumer type D3 (83.7 GJ). —-2 Consumer type I3-1 (41 860 GJ, 200 days, 1600 hours) Source: Eurostat.

crude oil. ${ }^{14}$ After rising strongly in 1999 and 2000 the average cross-border price of gas has fallen again, and in June 2004 it was 3.16 euros per gigajoule (GJ), or 1.14 cents per $\mathrm{kWh}$, according to the Federal Office of Economics and Export Control (BAFA).

There are big gaps in the statistical data on average gas prices in Germany, especially for the most recent developments. ${ }^{15}$ Eurostat gives gas prices for defined types of consumers and regions, ${ }^{16}$ and according to these figures the price of gas for households with about average annual consumption (type D3 at 83.7 GJ a year)

\footnotetext{
${ }^{14}$ It must be remembered that the prices for natural gas, unlike those for other energy sources, are generally related to the gross calorific value, which is around $10 \%$ higher than the net calorific value. Owing to adjustment for quantities in transit from Norway the import prices given by the Federal Office of Economics and Export Control (BAFA) or the Ministry of Economics and Labour (BMWA) differ from the figures given by the Federal Statistical Office.
}

was 12.73 euros per GJ, in Dortmund, including tax. Of this $12.0 \%$ was gas tax and $13.8 \%$ VAT (cf. figure 5). ${ }^{17}$ Thus, on a European comparison Germany is one of the countries with the highest gas prices (after Sweden, Denmark and Austria); the position is similar without tax as well (cf. figure 6).

15 The price statistics of the International Energy Agency (IEA) only give figures for gas prices in Germany up to the year 2000 in their issue for the second quarter of 2004. According to the Federal Statistical Office (March 2004), the price (average revenue) in 2002 had fallen by $8 \%$ from the previous year to 7.31 euros per GJ; for industry it was 5.42 euros per GJ and for other end-users 9.64 euros per GJ (all before VAT).

16 Eurostat: 'Gas prices for EU households on 1 January 2004' and 'Gas prices for EU industry on 1 January 2004', in: Statistics in focus, Environment and Energy, 4/5/2004 (manuscript completed on 18 June 2004). These figures include reported contract prices charged by gas suppliers but not individual discounts.

17 Related to the price including VAT. 


\section{Figure 7 \\ Electricity Prices ${ }^{1}$ in Germany 1996 to 2004 In cents per kWh}

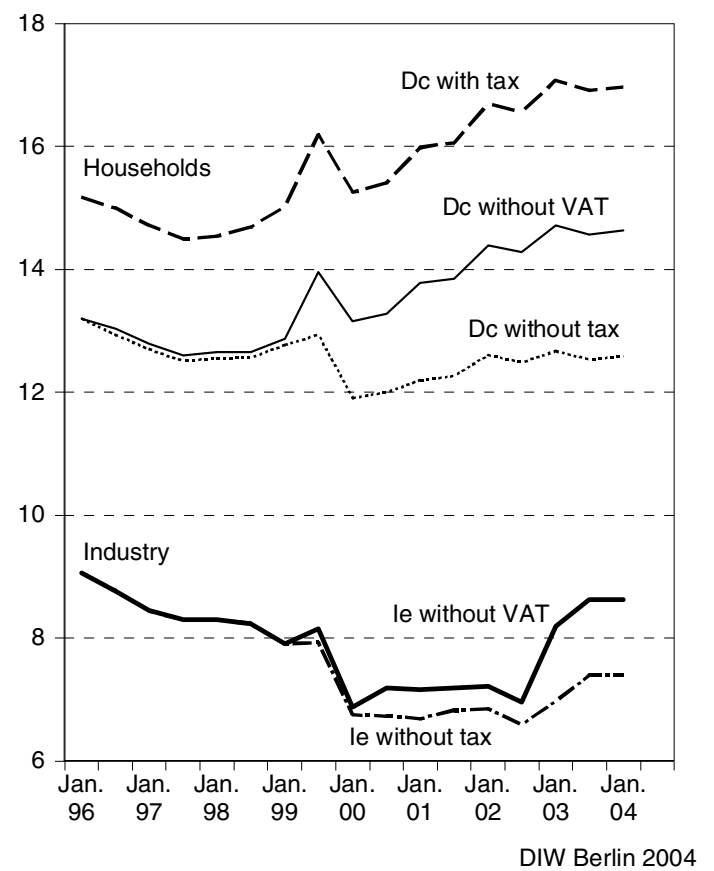

1 Prices for households (consumer type Dc) and industry (consumer type le) according to Eurostat.

Source: Eurostat.

Gas prices for industry are also relatively high in Germany. The price in Dortmund (without VAT) to consumer type I3-1 (41 $860 \mathrm{GJ}$ a year) on 1 January 2004 was 6.92 euros per GJ, $16 \%$ of which was gas tax. Only in Sweden and Austria was the price higher (cf. figure 6). Without gas tax the price was at about the same level as in Luxembourg, and so only slightly lower than in Finland and Sweden.

So far there has been little competition within the gas industry. ${ }^{18}$ One of the main aims of the current changes to the framework legislation on the energy industry in Europe and Germany ${ }^{19}$ is to increase the intensity of competition and so enable consumers to buy gas at lower cost. Important elements in the restructur-

\footnotetext{
18 Cf. Christian von Hirschhausen and Thorsten Becker: 'Reform der Erdgaswirtschaft in der EU und in Deutschland: Wie viel Regulierung braucht der Wettbewerb?' DIW Berlin Discussion Paper, no. 440, Berlin, September 2004; European Commission: 'Third Benchmark Report on the Implementation of the Internal Electricity and Gas Market', DG TREN Draft Working Paper, Brussels, 1 March 2004, European Commission: DG TREN: 'Towards a Competitive and Regulated European Electricity and Gas Market. Opening of the Internal Energy Market, Progress So Far', Brussels, July 2004.
}

ing are therefore 'unbundling' and the regulation of networks, especially to ensure free access. Unlike the electricity industry the gas industry has so far made little progress in opening the market in Germany.

\section{Electricity}

Electricity prices in Germany have fallen strongly since the liberalisation introduced in $1998^{20}$ as competition has increased. At times prices on the spot markets actually fell below the variable costs of some power stations. This has caused closures and concentration. Spot market prices rose from January 2002 to September 2004, from a good 2 cents per $\mathrm{kWh}$ to about 3 cents (Phelix Base $)^{21}$ but they are still below the total average costs of generating electricity in new power stations.

Electricity prices for industrial customers fell strongly in 1999, and then remained at the lower level until 2002 (cf. figure 7). Since then they have risen again, mainly due to tax increases. Without tax they are still lower than before liberalisation. Electricity prices to typical household customers also fell rapidly at first in 1999, before tax, but they then rose again gradually back to the former level. This was partly due to the growing costs for electricity users from the promotion of renewable energies and combined heat and power generation. With the eco tax electricity prices to households have risen markedly in recent years. ${ }^{22}$

On a European comparison typical households and industrial customers in Germany are charged relatively high prices for electricity. Pre-tax prices to household customers consuming $3500 \mathrm{kWh}$ a year are only higher in Italy and Portugal, and with tax in Denmark, Italy and the Netherlands (cf. figure 8). Industrial customers consuming 2000 MWh a year (type Ie), only pay more, without tax, in Belgium, Ireland, Italy and Cyprus, and with tax only in Italy (cf. figure 8).

Compared with other European countries Germany has relatively high charges for use of the grid. These differences can be due to differences in infrastructure conditions or the exploitation of market power by network

\footnotetext{
19 Directive 2003/55/EC of the European Parliament and the Council of 26 June Concerning Common Rules for the Internal Gas Market, Official Journal L 176, 15 July 2003; German Federal Government: Draft of a Second Act to Amend the Energy Industry Legislation of 28 July 2004. The Upper House rejected the proposed draft on 24 September 2004.

${ }^{20}$ Act to Amend the Energy Industry Legislation of 24 April 1998.

${ }^{21}$ European Energy Exchange (www.ex.de).

22 According to data from the VDEW (press release September 2004), the electricity bill for the average household now includes 13.8\% VAT, $11.4 \%$ electricity tax, $10 \%$ concession charge, $3 \%$ for renewable energies and $1.6 \%$ for combined heat and power generation.
} 
Figure 8

Electricity Prices for Households ${ }^{1}$ and Industry ${ }^{2}$ in Europe on 1 January 2004

In cents per kWh
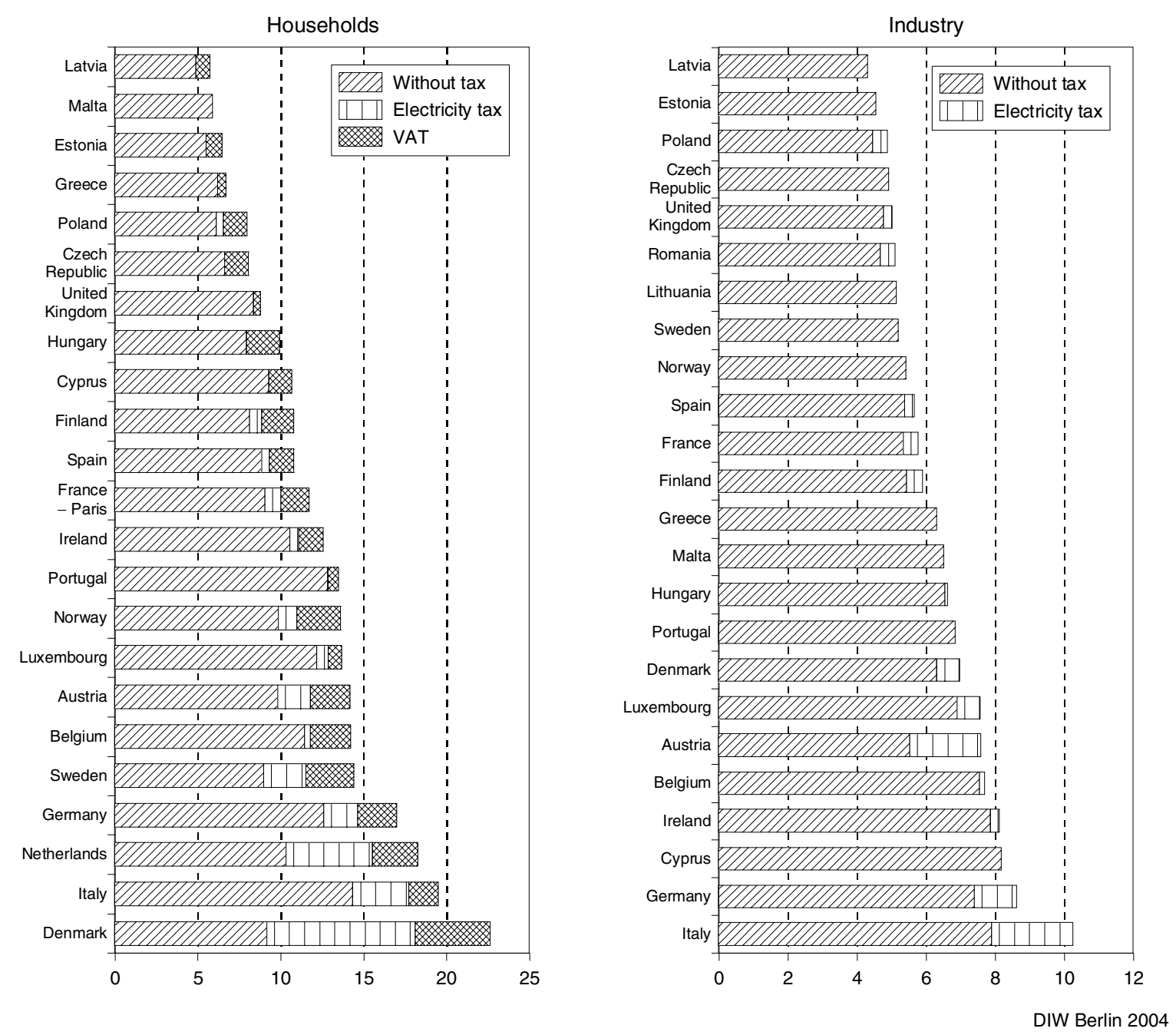

1 Consumer type Dc (3500 kWh). - 2 Consumer type le (2000 MWh, 4000 hours). Source: Eurostat.

operators. Further intensification of competition could lead to lower prices. The regulatory authority could make a contribution here; it will be able to take action after the new energy legislation comes into force. ${ }^{23}$

\section{The energy consumer price index}

The price trends for all energy consumption by private households (including fuels) are summarised in the harmonised consumer price index for energy which is com-

\footnotetext{
${ }^{23}$ Cf. footnotes 18 and 19
}

piled by Eurostat (with 1996 as the base year, cf. figure 9). It shows that energy prices in Germany rose by $38.4 \%$ from 1996 to August 2004, i.e. rather more than in the EU-25 (34.6\%) and clearly more than in the EU-15 $(28.4 \%){ }^{24}$ However, the increase in consumer prices for energy since September 2003 in Germany has been $6.9 \%$, about as high as in the EU-25 and the EU-15 $(6.5 \%$ each), so that the energy price disadvantages for private households did not increase further last year.

${ }^{24}$ While energy prices in Slovakia and Poland more than doubled during that period, they rose less in Lithuania, France, Greece and Italy (by less than $20 \%$ ). 


\section{Figure 9

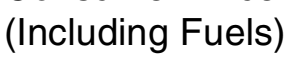

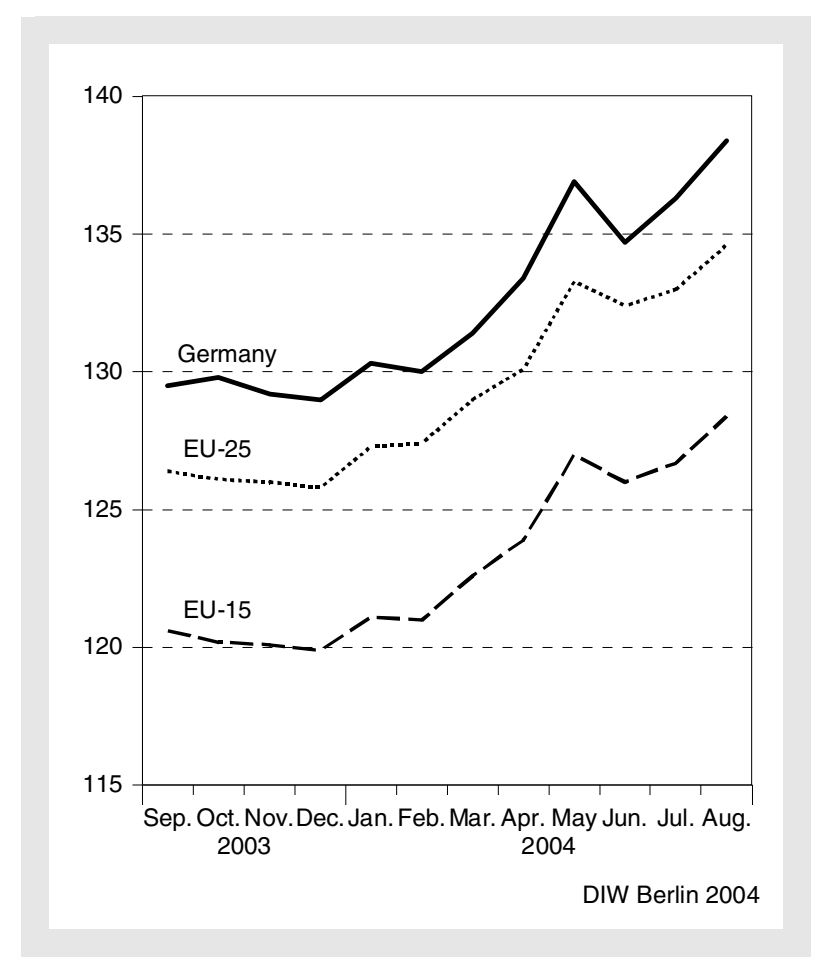

Source: Eurostat.

\section{Conclusion}

Starting from a low level in 1999, international crude oil prices have since more than quadrupled. This is due to higher demand worldwide, a shortage of production capacities, individual shortfalls in production and uncertainties that still persist. The development on the oil market is not only affecting prices at the pumps and sales of heating oil, but also the coal and gas markets. In addition, taxes on petroleum products, gas and electricity, have been increased in recent years. Another reason for the high energy prices is that competition on the markets for electricity and gas is still inadequate. By comparison with other European countries energy is relatively expensive at present in Germany, to both industry and private households.

Some of the increases in energy prices in Germany are an inevitable result of environmental policy. With regard to the environment, higher charges for energy consumption should help to reduce the emission of carbon dioxide in accordance with international and European agreements. The EU directive on the minimum taxation of energy will reduce the tax differentials in the enlarged EU, and energy prices in some neighbouring countries will rise, if only to a limited extent and only after various transition phases.

Competition in electricity and gas supplies is to be intensified in future on the basis of the EU directives on opening up the internal market. The main aim is to open up access to networks and avoid excessive charging for network use. Germany first has to decide on the amendments to the energy industry legislation, so that the regulatory authority can commence operating. The increases in efficiency this is expected to bring are welcome, although it is not to be expected that in the short term they will compensate for the influence of the international energy markets in raising prices.

Jochen Diekmann, Manfred Horn, Claudia Kemfert and Uwe Kunert 